\title{
Mechanism of Activity-Dependent Downregulation of the Neuron-Specific K-Cl Cotransporter KCC2
}

\author{
Claudio Rivera, ${ }^{1,2}$ Juha Voipio, ${ }^{1}$ Judith Thomas-Crusells, ${ }^{2}$ Hong Li, ${ }^{1,2}$ Zsuzsa Emri, ${ }^{1}$ Sampsa Sipilä, ${ }^{1}$ John A. Payne, ${ }^{3}$ \\ Liliana Minichiello, ${ }^{4}$ Mart Saarma, ${ }^{2}$ and Kai Kaila ${ }^{1}$ \\ ${ }^{1}$ Department of Biosciences and ${ }^{2}$ Institute of Biotechnology, University of Helsinki, Helsinki, FIN-00014 Finland, ${ }^{3}$ Department of Human Physiology, \\ University of California School of Medicine, Davis, California 95616, and ${ }^{4}$ European Molecular Biology Laboratory, 00016 Monterotondo, Italy
}

\begin{abstract}
GABA-mediated fast-hyperpolarizing inhibition depends on extrusion of chloride by the neuron-specific K-Cl cotransporter, KCC2. Here we show that sustained interictal-like activity in hippocampal slices downregulates KCC2 mRNA and protein expression in CA1 pyramidal neurons, which leads to a reduced capacity for neuronal $\mathrm{Cl}^{-}$extrusion. This effect is mediated by endogenous BDNF acting on tyrosine receptor kinase B (TrkB), with down-stream cascades involving both Shc/FRS-2 (src homology 2 domain containing transforming protein/FGF receptor substrate 2) and PLC $\gamma$ (phospholipase $\mathrm{C} \gamma$ )-cAMP response element-binding protein signaling. The plasmalemmal KCC2 has a very high rate of turnover, with a time frame that suggests a novel role for changes in KCC2 expression in diverse manifestations of neuronal plasticity. A downregulation of KCC2 may be a general early response involved in various kinds of neuronal trauma.
\end{abstract}

Key words: BDNF; neurotrophic factors; intracellular chloride; activity-dependent gene expression; GABAergic transmission; epilepsy

\section{Introduction}

There is ample evidence that $\mathrm{K}-\mathrm{Cl}$ cotransport is responsible to a large extent for neuronal $\mathrm{Cl}^{-}$extrusion and hence for the generation of $\mathrm{Cl}^{-}$-dependent hyperpolarizing postsynaptic currents mediated by ionotropic $\mathrm{GABA}_{\mathrm{A}}$ and glycine receptors (Thompson and Gähwiler, 1989; Kaila, 1994; Payne et al., 2003). Expression of the neuron-specific $\mathrm{K}-\mathrm{Cl}$ cotransporter $\mathrm{KCC} 2$ is required for the generation of the inwardly directed $\mathrm{Cl}^{-}$electrochemical gradient in CA1 pyramidal neurons of the rat hippocampus (Rivera et al., 1999) and several other types of neurons (Lu et al., 1999; Williams et al., 1999; DeFazio et al., 2000; Kakazu et al., 2000; Ganguly et al., 2001; Hubner et al., 2001).

Interestingly, short- and long-term shifts from hyperpolarizing to depolarizing (sometimes even excitatory) $\mathrm{GABA}_{\mathrm{A}}$ mediated responses have been observed under various experimental conditions, including tetanic stimulation, neuronal trauma, GABA uptake block, and axotomy, as well as pharmacologically induced epileptiform activity (Kapur and Coulter, 1995; Avoli, 1996; van den Pol et al., 1996; Kaila et al., 1997; Jackson et al., 1999; Voipio and Kaila, 2000; Nabekura et al., 2002). In addition, spontaneous network activity associated with depolarizing postsynaptic $\mathrm{GABA}_{\mathrm{A}}$ responses has been seen in human neocortical tissue resected for treatment of temporal lobe epilepsy (Avoli et al., 1995; Köhling et al., 1998; Cohen et al., 2002).

\footnotetext{
Received Nov. 28, 2003; revised April 7, 2004; accepted April 7, 2004.

This work was supported by the Academy of Finland and by the Sigrid Jusélius Foundation. M.S., K.K., and C.R. are Fellows of the Biocentrum Helsinki. We thank Marjo Heikura and Miika Palviainen for excellent technical assistance.

Correspondence should be addressed to Dr. Claudio Rivera, Institute of Biotechnology, P.0. Box 56, University of Helsinki, FIN-00014 Finland. E-mail: Claudio.Rivera@helsinki.fi.

Z. Emri's present address: Chemical Research Center, $\mathrm{H}-1025$ Budapest, Hungary

DOI:10.1523/JNEUROSCI.5265-03.2004

Copyright $\odot 2004$ Society for Neuroscience $\quad 0270-6474 / 04 / 244683-09 \$ 15.00 / 0$
}

Activation of tyrosine receptor kinase B (TrkB) receptors by BDNF leads to autophosphorylation of tyrosine residues within the intracellular domain of the receptor, creating docking sites for proteins such as src homology 2 domain containing transforming protein (Shc) and FGF receptor substrate 2 (FRS-2) and phospholipase $\mathrm{C} \gamma$ (PLC $\gamma)$ that activate second messengers and other downstream effectors. These include the cAMP response element-binding protein (CREB), which couples to the transcriptional machinery in the nucleus and thereby controls the expression of a wide variety of genes linked to long-term changes in neuronal plasticity (Finkbeiner et al., 1997; Bibel and Barde, 2000; Minichiello et al., 2002).

We have shown recently that KCC2 in the hippocampus is downregulated after kindling-induced seizures in vivo and also by applying exogenous BDNF or neurotrophin 4 in vitro (Rivera et al., 2002). These data, although suggestive, did not demonstrate a causal link between enhanced neuronal activity and TrkBmediated downregulation of KCC2. In the present work, we provide direct evidence to show that in hippocampal CA1 pyramidal neurons, KCC2 is downregulated by continuous, synchronous neuronal activity via endogenous BDNF-TrkB signaling, which recruits both Shc and PLC $\gamma$-coupled intracellular pathways. The plasmalemmal KCC2 has a very high rate of turnover, which provides a time frame that is compatible with a role for changes in KCC2 expression in various manifestations of neuronal plasticity.

\section{Materials and Methods}

Hippocampal slices. Hippocampal slices from Wistar rats (Rivera et al., 2002 ) and the mutant $\operatorname{trkB}^{P L C / P L C}, \operatorname{trkB}^{S H C / S H C}$, and $\operatorname{trkB}{ }^{W / W}$ mice (Minichiello et al., 2002) were prepared using a Vibratome (Technical Products International). The standard physiological solution contained 
(in mM): $124 \mathrm{NaCl}, 3.0 \mathrm{KCl}, 2.0 \mathrm{CaCl}_{2}, 25 \mathrm{NaHCO}_{3}, 1.1 \mathrm{NaH}_{2} \mathrm{PO}_{4}, 2.0$ $\mathrm{MgSO}_{4}$, and $10 \mathrm{D}$-glucose, and was equilibrated with $95 \% \mathrm{O}_{2}$ and $5 \%$ $\mathrm{CO}_{2}$ to yield a $\mathrm{pH}$ of 7.4 at the experimental temperature, $+32^{\circ} \mathrm{C}$. Slices were left to recover at room temperature for $\sim 1 \mathrm{hr}$ and thereafter transferred into a submerged-type (double-sided perfusion) chamber. $\mathrm{MgSO}_{4}$ was omitted in the $0-\mathrm{Mg}^{2+}$ solution. 4-Aminopyridine (AP) (applied at 100 $\mu \mathrm{M})$, 2,3-dihydroxy-6-nitro-7-sulfonyl-benzo[f]quinoxaline (NBQX) (10 $\mu \mathrm{M})$, and DL-AP-5 $(40 \mu \mathrm{M})$ were obtained from Tocris Cookson.

Interictal-like activity is generated in the absence of $\mathrm{Mg}^{2+}$ in slices kept under both interface and submerged conditions (Anderson et al., 1986; Mody et al., 1987; Beau and Alger, 1998). Because it turned out to be much easier to obtain quantitatively reproducible data under submerged conditions for the large number of slices required in the RT-PCR measurements and Western blots, as well as immunohistochemical and biotinylation experiments (see below), all experiments were done on submerged slices.

Electrophysiology. Field potentials were recorded using glass microelectrodes filled with $150 \mathrm{~mm} \mathrm{NaCl}$. Intracellular recordings were made from rat CA1 pyramidal cells using microelectrodes filled with $0.5 \mathrm{~m} \mathrm{~K}$-acetate plus $0.5 \mathrm{M} \mathrm{KCl}$, pH 6.6-6.8 (resistance 135-220 M 2 ). Recordings were discarded if electrodes showed rectification or time-dependent changing of electrode resistance during current pulses. In a few experiments, 50 mM $N$-ethyl bromide quaternary salt (QX-314) was added to the microelectrode filling solution. An Axoclamp 2B amplifier (Axon Instruments, Foster City, CA) was used in either bridge or discontinuous current passing mode. Cells with a stable resting membrane potential of at least $-55 \mathrm{mV}$ (see Results) and input resistance of $38-126 \mathrm{M} \Omega$ were used in the measurements. Inhibitory postsynaptic responses were evoked in the presence of the ionotropic glutamate antagonists by stimuli $(16-28 \mathrm{~V}$, $60-100 \mu \mathrm{sec}$, frequency $1 / 10$ or $1 / 15 \mathrm{~Hz}$ ) delivered via a bipolar tungsten electrode positioned close $(\leq 500 \mu \mathrm{m})$ to the recording electrode (Davies et al., 1990). Responses with spikes interfering with the $\operatorname{IPSP}_{\mathrm{A}}$ amplitude measurement were discarded from $E_{\text {IPSP-A }}$ analysis.

$R T$-PCR. RT-PCR analysis was performed as described previously (Rivera et al., 1999). Briefly, total RNA from the slices was extracted with Trizol (Sigma, St. Louis, MO) using a modified version of the protocol by Chomczynski and Sacchi (1987). Total RNA was reverse transcribed using random hexamer primers and SuperscriptII reverse transcriptase (Invitrogen, Gaithersburg, MD). Oligodeoxynucleotide primers were synthesized over regions specific for light neurofilament (NF-L), neuron-specific enolase (NSE), or KCC2 cDNA. For NF-L, forward (5'-GCACATCTCCAGCGTGCGCAG-3') and reverse (5'-GGATCTGAGCCTGCAGCTCGG-3') primers were used to amplify a 120 bp fragment. For KCC2, forward (5'-CTCAACAACCTGACGGACTG-3') and reverse (5'-GCAGAAGGACTCCATGATGCCTGCG-3') primers were used to amplify a $399 \mathrm{bp}$ fragment (bp 4-402 in KCC2). For NSE, forward $\left(5^{\prime}\right.$-CTCTACCAGGACTTTGTCCGG-3') and reverse ( $5^{\prime}$-GGGACAGCAAGAAAGAGGCT$\left.3^{\prime}\right)$ primers were used to amplify a $600 \mathrm{bp}$ fragment.

Immunoblotting. Crude membrane fractions were prepared from slices in homogenization buffer $(250 \mathrm{~mm}$ sucrose, $10 \mathrm{~mm}$ Tris, $10 \mathrm{~mm}$ HEPES, $1 \mathrm{~mm}$ EDTA; pH adjusted to 7.2 at $+24^{\circ} \mathrm{C}$, containing protease inhibitors by differential centrifugation). Membrane proteins were separated by SDS-PAGE, electrophoretically transferred to polyvinylidene difluoride or nitrocellulose membranes, and immunoblotted as described previously (Payne et al., 1996) using affinity-purified rabbit anti-KCC2 polyclonal antibodies (B2C; 1:1000), rabbit anti-phosphoCREB (pCREB) (1:1000; Upstate Biotechnology, Lake Placid, NY), and rabbit anti- $\alpha$-tubulin (1:
10000; Sigma). Bands were developed using ECL-plus (Amersham, Arlington Heights, IL) on $\mathrm{x}$-ray films as well as on a phosphoimager BAS-1500 (Fujifilm) and analyzed with TINA software (Tamro).

Immunohistochemistry. Slices were washed three times in PBS $(0.1 \mathrm{M}$ phosphate buffer, $\mathrm{pH} 7.4,0.9 \% \mathrm{NaCl}$ ) and immersion-fixed in $4 \%$ PFA overnight. They were then processed into paraffin and sectioned (10-14 $\mu \mathrm{m})$. The sections were dewaxed in xylene and rehydrated through a graded series of aqueous ethanol. The slices were washed three times in $\mathrm{PBS}$ and then placed in BSA/PBS (PBS containing $0.2 \%$ Triton X-100, $2 \% \mathrm{BSA}$ ) for $2 \mathrm{hr}$ at room temperature. Sections were incubated at $+4^{\circ} \mathrm{C}$ for $48 \mathrm{hr}$ with primary antibody $(\mathrm{Ab})$ diluted in BSA/PBS. Rabbit antiKCC2 (B2C) Ab was diluted 1:200 (Payne et al., 1996), and rabbit antipCREB was diluted 1:200 (Upstate Biotechnology). After three PBS washes they were incubated for $2 \mathrm{hr}$ with FITC-conjugated or tetramethylrhodamine isothiocyanate (TRITC)-conjugated goat anti-rabbit IgG (1:200; Jackson ImmunoResearch, West Grove, PA). Sections were then washed three times in PBS and once in distilled water and mounted on Superfrost Plus (Menzel-Glaser) slides with 4,6-diamidino-2phenylindol (DAPI) (Sigma) containing gelvatol (Biomedia). For assessment of acute cell death (Poirier et al., 2000), DAPI-positive nuclei were counted in five frames of $100 \times 200 \mu \mathrm{m}$ randomly placed on the CA1 stratum pyramidale.

Regional and experimentally induced differences in immunofluorescence intensity were quantified with TINA software. The intensity was integrated over a given area in a slice (see Fig. $2 A$ ), and when the experimental data (see Fig. $2 \mathrm{~B}$ ) were pooled, each data point was based on at least three sections from a given slice. Confocal immunofluorescence microscopy was performed with a Bio-Rad MRC-1024 confocal microscope system (Bio-Rad, Hercules, CA) equipped with an argon-krypton ion laser (American Laser Corporation) and an Axiovert 135M using a $63 \times$ oil numerical aperture 1.4 objective (Carl Zeiss, Oberkochen, Germany). TRITC-stained samples were imaged by excitation at $568 \mathrm{~nm}$ and with a 598-621 nm bandpass emission filter. Optical sections were taken at every $0.6 \mu \mathrm{m}$.

In situ hybridization. A 1039 bp mouse KCC2 expressed sequence tag clone (AA982489), corresponding to nucleotides 4605-5566 of the full-
A

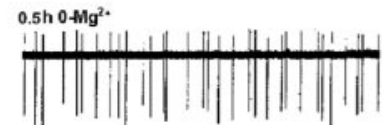

$1 \mathrm{~h} 0 \rightarrow \mathrm{Mg}^{2}$.
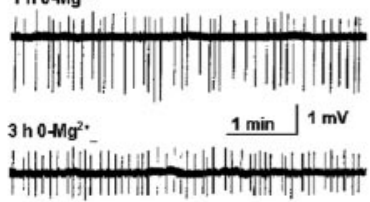

C

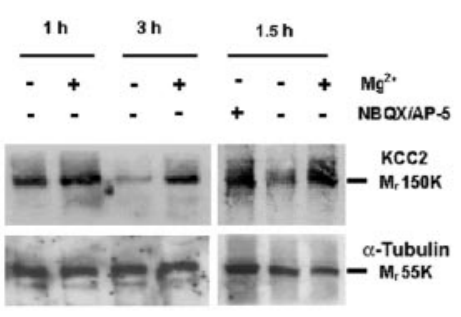

B

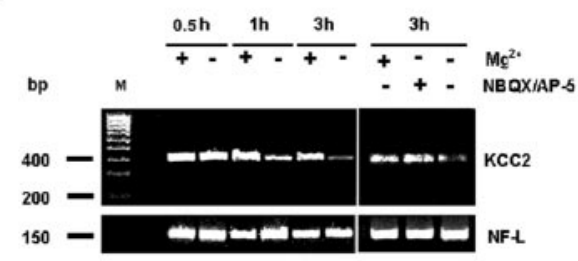

D

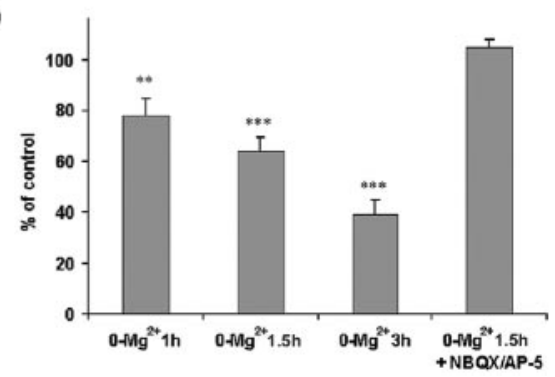

Figure 1. Interictal-like activity leads to a downregulation of KCC2 protein and mRNA levels in acute hippocampal slices. $A$, Extracellular field potentials in CA1 stratum pyramidale at $0.5,1$, and $3 \mathrm{hr}$ after withdrawal of $\mathrm{Mg}^{2+}$. B, RT-PCR shows that KCC2 mRNA is downregulated, whereas NF-L mRNA remains constant. C, Western blots show activity-dependent downregulation of the KCC2 protein ( $150 \mathrm{kDa}$ band) after 1-3 hr in 0-Mg ${ }^{2+}$. KCC2 mRNA and protein are not downregulated in slices in which $0-\mathrm{Mg}^{2+}$-induced activity was blocked with $10 \mu \mathrm{M}$ NBQX and $40 \mu \mathrm{M} \mathrm{DL}-A P-5(B, C)$, showing an activity-specific effect. $\alpha$-Tubulin was used to monitor the amount of total protein. $D$, Statistical representation of optical densities from five experiments such as those in C, expressed as percentage of control (means \pm SEM; $t$ test; ${ }^{* * *} p<0.001$; ${ }^{* *} p<0.01$ ). 
length rat KCC2 cDNA (Payne et al., 1996), was used for the synthesis of labeled cRNA KCC2 probe (Hiltunen et al., 1996). Free-floating in situ hybridization was performed on $100 \mu \mathrm{m}$ sections obtained from cutting thick acute hippocampal slices $(350 \mu \mathrm{m})$ and using digoxigenin-labeled riboprobes as described (Nieto et al., 1996).

Biotinylation assay of membrane surface KCC2. To examine the rate of decay of plasmalemmal KCC2, we used a recently developed method for membrane surface biotinylation in acute slice preparations (ThomasCrusells et al., 2003). Slices were placed in an experimental chamber and incubated on ice in the standard physiological solution $\left(95 \% \mathrm{O}_{2} / 5 \%\right.$ $\mathrm{CO}_{2}$ ) containing biotin-sulfo- $N$-hydroxysuccinimide (100 $\mu \mathrm{M}$; Sigma). After $1 \mathrm{hr}$, slices were rinsed with cold physiological solution containing $1 \mu \mathrm{M}$ lysine (Sigma) to stop the reaction. Thereafter, the temperature was raised to $+32^{\circ} \mathrm{C}$, and the slices were exposed to the various experimental conditions (see Fig. 4), collected, and lysed at fixed time points in a solution containing 1\% Triton X-100, 0.1\% SDS, 1 mm EDTA, $50 \mathrm{~mm}$ $\mathrm{NaCl}, 20 \mathrm{~mm}$ Tris- $\mathrm{HCl}, \mathrm{pH}$ 7.5, and protease inhibitors (Roche, Hertfordshire, UK). The lysates were precipitated with streptavidin-Sepharose beads (Roche) by overnight incubation at $+4^{\circ} \mathrm{C}$ followed by a brief centrifugation. The beads were washed with $\mathrm{PBS}$ and stored at $-70^{\circ} \mathrm{C}$ until use. The samples were run through a $10 \%$ ready-gel SDS-PAGE (Bio-Rad), transferred to nitrocellulose membrane (Hybond ECL; Amersham Biosciences), and blotted at $+4^{\circ} \mathrm{C}$ overnight with rabbit anti-rat KCC2 (B2C) primary Ab (1:2000) and mouse anti-human transferrin receptor primary Ab (1:2000; Zymed Laboratories,San Francisco, CA). Incubation with the secondary $\mathrm{Ab}$ (goat anti-rabbit IgG-peroxidase, 1:4000, and goat anti-mouse IgG-peroxidase, 1:4000; Sigma) was for $1 \mathrm{hr}$ at room temperature. For calculation of the rate of KCC2 decay, the density of the bands was analyzed with the TINA software, and the data were fitted by regression analysis to the equation $f(t)=y_{0}+a e^{-t / \tau}$, where $a$ is the amplitude of the decline of biotinylated KCC2 protein, $y_{O}$ is the apparent baseline level in the present experiments, $t$ is the time from the onset of the experiment, and $\tau$ is the time constant of the exponential decay.

Statistics. The data are presented as mean \pm SEM. Statistical analysis was performed using nonpaired Student's $t$ test. Statistical significance was defined as $p<0.01\left(^{* *}\right)$ and $\left.p<0.001{ }^{* * *}\right)$.

\section{Results}

Effect of interictal-like activity on KCC2 mRNA and protein levels

Exposure of hippocampal slices to a solution devoid of $\mathrm{Mg}^{2+}$ $\left(0-\mathrm{Mg}^{2+}\right)$ resulted in the generation of continuous interictal-like activity (Anderson et al., 1986; Mody et al., 1987), which commenced at $\sim 10-15 \mathrm{~min}$ and showed a progressive increase in frequency during the 1-3 hr recording sessions (Fig. 1A). As shown by RT-PCR, there was a progressive fall in KCC2 mRNA after $1-3 \mathrm{hr}$ in the $\mathrm{Mg}^{2+}$-free solution when compared with control slices or slices exposed to the $0-\mathrm{Mg}^{2+}$ solution for $30 \mathrm{~min}$ only (Fig. $1 B)(n=4)$.

In Western blot analyses, the $\sim 150 \mathrm{kDa}$ band that corresponds to the glycosylated form of KCC2 protein (Rivera et al., 1999; Williams et al., 1999) showed a pronounced fall during $0-\mathrm{Mg}^{2+}$ exposure for $1-3 \mathrm{hr}$ (Fig. 1 C). A slight decline with a rate of $\sim 0.2 \% / \mathrm{min}$ was seen under control conditions. To address whether the prompt downregulation of KCC2 was caused by the withdrawal of $\mathrm{Mg}^{2+}$ per se or by the consequent discharge activity, we blocked the activity by using NBQX plus AP-5 (Anderson et al., 1986; Mody et al., 1987). Under these conditions, KCC2 mRNA as well as protein levels were retained at a level that was indistinguishable from that obtained from parallel controls (Fig. $1 B, C$ ).

Figure $1 D$ shows a compilation of quantitative data obtained in Western blots from experiments terminated at 1-3 hr. The relative fall of KCC2 protein in slices with interictal-like activity versus time-matched controls was $22 \pm 7 \%(p<0.01)$ at $1 \mathrm{hr}, 36 \pm 5 \%$ $(p<0.001)$ at $1.5 \mathrm{hr}$, and $61 \pm 5 \%$ at $3 \mathrm{hr}(p<0.001 ; n=5)$.
A
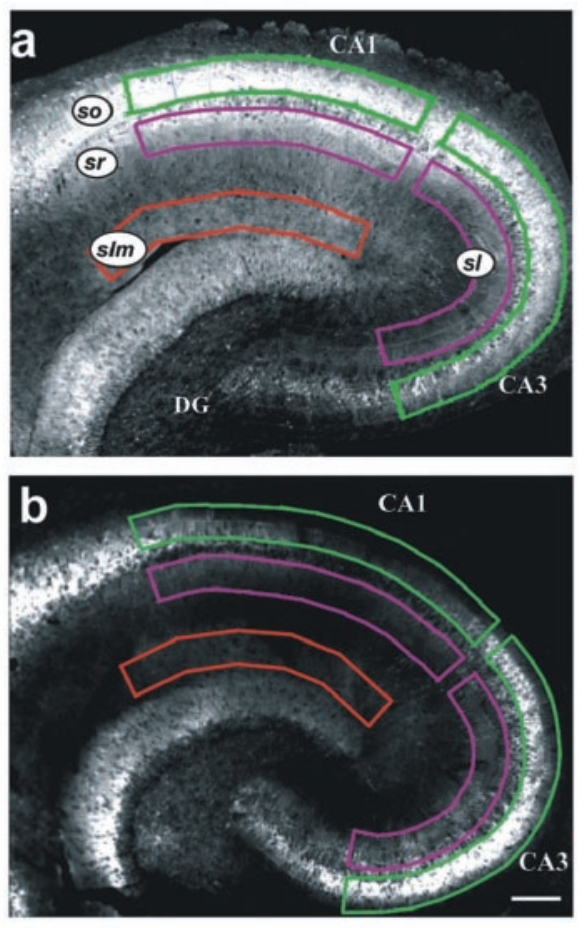

\section{B}

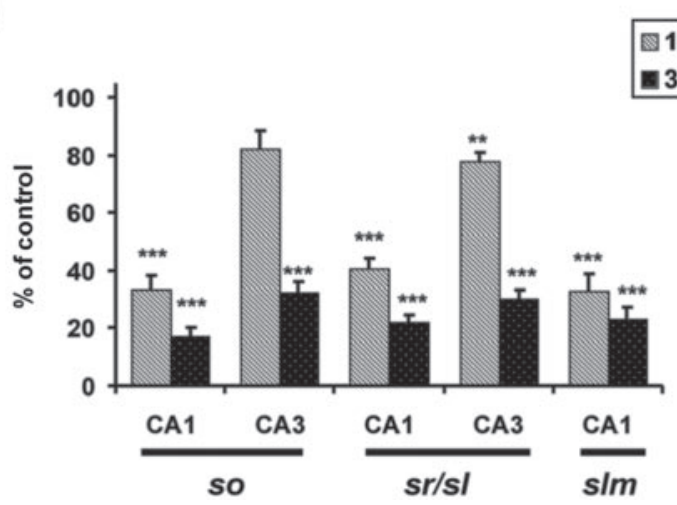

Figure 2. Area-specific decrease of $\mathrm{KCC} 2$ immunofluorescent staining in slices exposed to the $0-\mathrm{Mg}^{2+}$ solution. $A$, Slices superfused for $1 \mathrm{hr}$ in control solution $(A a)$ and in the $\mathrm{Mg}^{2+}$-free solution $(A b)$. Note the pronounced reduction in staining intensity in CA1. so, Stratum oriens; $\mathrm{Sr}$, stratum radiatum; $\mathrm{sl}$, stratum lucidum; $\mathrm{s} \mathrm{Im}$, stratum lacunosum-moleculare; DG, dentate gyrus). $B$, Plot of optical intensities from the distinct areas marked in $A a$ and $A b$ after 1 and $3 \mathrm{hr}$ of $0-\mathrm{Mg}^{2+}$ superfusion. ( $t$ test; ${ }^{* * *} p<0.001 ; n=10$.) Scale bar, $400 \mu \mathrm{m}$.

\section{Effect of interictal-like activity on area-specific KCC2 expression patterns}

Figure $2 \mathrm{~A}$ shows the distribution of KCC2 immunofluorescent staining in slices superfused with standard $(n=10)$ or $0-\mathrm{Mg}^{2+}$ solution $(n=10)$ for $1 \mathrm{hr}$. After $1 \mathrm{hr}$ under control conditions (Fig. 2Aa), the KCC2 staining pattern is similar to the one observed in perfused brain sections (Gulyas et al., 2001). The immunoreactivity of the plasmalemmal KCC2 in the dendrites of principal cells is mainly responsible for the diffuse staining found in the neuropil (Gulyas et al., 2001). We found that, also in acute slices, the intensity of the diffuse neuropil staining in CA1 is strongest in stratum oriens (Fig. $2 \mathrm{Aa}$ ) close to stratum pyramidale and decreases along the stratum radiatum. The staining intensity increases again close to the stratum lacunosummoleculare border. In CA3, KCC2 staining was high in stratum 
oriens, but in stratum lucidum, the overall staining was less intense than in the apical dendritic regions in CA1.

In agreement with the data from Western blots, we observed a clear fall in the KCC2 staining intensity in slices exposed to the $0-\mathrm{Mg}^{2+}$ solution (Fig. $2 \mathrm{Ab}$ ). This decrease was most conspicuous in the CA1 region, where the pyramidal neurons are well known for their high vulnerability to a wide variety of pathological insults (Schmidt-Kastner and Freund, 1991).

To compare in more quantitative terms the effects of $0-\mathrm{Mg}^{2+}$ exposure on the expression patterns of KCC2, we measured the area-specific intensity profiles of the immunofluorescence signal (Fig. 2A). The intensity of each region in $0-\mathrm{Mg}^{2+}$ slices was compared with the corresponding region in parallel control slices. A statistical quantification is provided in Figure $2 B$, which clearly indicates that after $1 \mathrm{hr}$ in $0-\mathrm{Mg}^{2+}(n=10)$, the expression of KCC2 in CA1 was downregulated on average by $>60 \%$ relative to controls $(n=10)$ in all layers examined. The corresponding changes in CA3 were much smaller: $\sim 20 \%$. Superfusion of the slices (control, $n=9$; $0-\mathrm{Mg}^{2+}, n=9$ ) for $3 \mathrm{hr}$ in the $0-\mathrm{Mg}^{2+}$ solution led to a further decrease in KCC2 protein levels in all regions examined (Fig. 2 B).

Because no significant difference in the number of DAPIpositive nuclei (see Materials and Methods) was found in the CA1 region between control slices $(n=9)$ and those exposed for $3 \mathrm{hr}$ to $0-\mathrm{Mg}^{2+}(16 \pm 2$ vs $14 \pm 3$ nuclei per $100 \times 200 \mu \mathrm{m}$ frame; $n=$ 9 ), the reduced intensity in KCC2-positive staining observed in the CA1 region cannot be explained on the basis of an acute $0-\mathrm{Mg}^{2+}$-induced cell death.

Interictal-like activity induced by the convulsant drug 4-AP $(100 \mu \mathrm{M})$ for $1 \mathrm{hr}$ in acute hippocampal slices (data not shown) (Avoli, 1996; Lamsa and Kaila, 1997) also induced downregulation of KCC2 (Fig. 3). Free-floating nonradioactive in situ hybridization showed a general downregulation of KCC2 mRNA as compared with control slices $(n=4)$. A more pronounced effect was observed in the CA3 and dentate gyrus (Fig. 3A). Parallel Western blot analyses showed a clear downregulation of KCC2 protein levels $(35 \pm 9 \% ; p<0.001)$ in response to 4 -AP exposure (Fig. $3 B)(n=4)$. These data provide further evidence for the view that the activity-dependent effects observed in $0-\mathrm{Mg}^{2+}$ are not attributable to the withdrawal of magnesium per se.

\section{Rapid degradation of cell-surface biotinylated KCC2 protein} Under steady state, the rate of incorporation of KCC2 molecules into the cell surface membrane must equal the rate of their removal and subsequent degradation. To gain information on the turnover of plasmalemmal KCC2, we used Western blot analyses of the surface-biotinylated KCC2 protein (B-KCC2) (ThomasCrusells et al., 2003). Biotinylated transferrin receptors (B-TfRs) were used as controls because they show a very low turnover rate (Mellman, 1996).

A quantification of the average density of the individual bands obtained in the Western blots (Fig. $4 A$ ) indicated a very fast decay of B-KCC2 protein under control conditions, with a time constant $(\tau)$ of $19 \pm 1 \mathrm{~min}(n=7)$ (Fig. $4 B)$. In the above experiments, a baseline B-KCC2 level of $\sim 20 \%$ was seen (Fig. $4 B$ ). The slow kinetics of this protein fraction was not studied further.

An additional interesting observation here was that, in
A
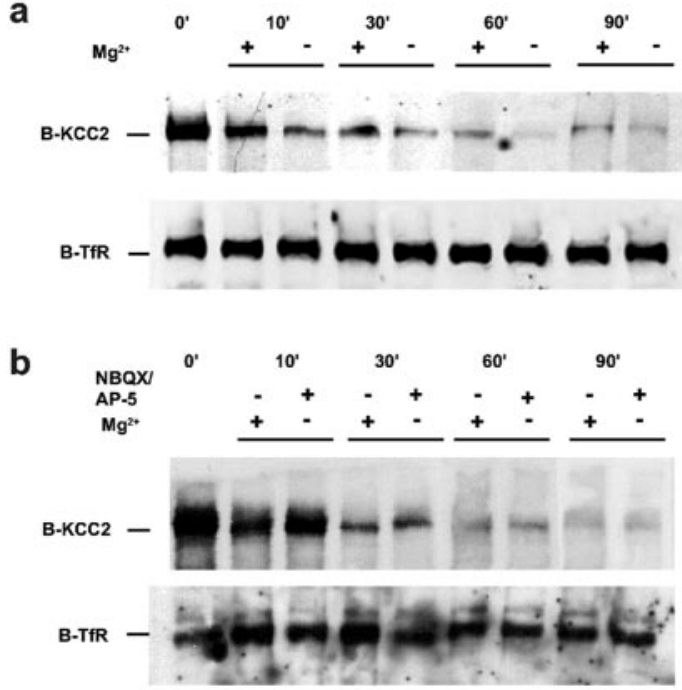

B

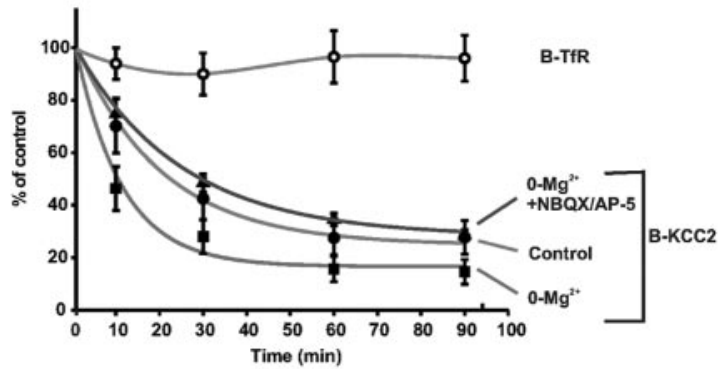

Figure 4. Decay of cell surface biotinylated $K C C 2$. Aa, Western blot of streptavidinprecipitated $\mathrm{B}-\mathrm{KCC} 2$ showing a very fast rate of fall of $\mathrm{B}-\mathrm{KCC} 2$ protein under control conditions that was enhanced further by omission of extracellular $\mathrm{Mg}^{2+}$. The level of plasmalemmal $B-T f R$ does not show any significant change within $90 \mathrm{~min}$. $A b$, The application of NBQX (10 $\mu \mathrm{m})$ and DL-AP-5 $(40 \mu \mathrm{M})$ blocked the enhancing effect of $0-\mathrm{Mg}^{2+}$ on the rate of decline of B-KCC2. $B$, Plot of normalized B-KCC2 and B-TfR optical band intensities from experiments such as shown in $A$.

$0-\mathrm{Mg}^{2+}$, the rate of the decay of B-KCC2 was increased further, to yield a $\tau$ of $10 \pm 3 \min (p<0.01 ; n=5)$. This effect was fully attributable to the interictal-like activity and not to the omission of $\mathrm{Mg}^{2+}$, because in experiments with ionotropic glutamate antagonists the rate of B-KCC2 decay in $0-\mathrm{Mg}^{2+}$ was identical if not slightly lower ( $\tau=25 \pm 3 \mathrm{~min} ; n=5$ ) than that prevailing under control conditions (Fig. 4Ab,B). Notably, the B-TfR levels remained virtually constant.

These experiments show that KCC2 molecules, once incorpo- 
A
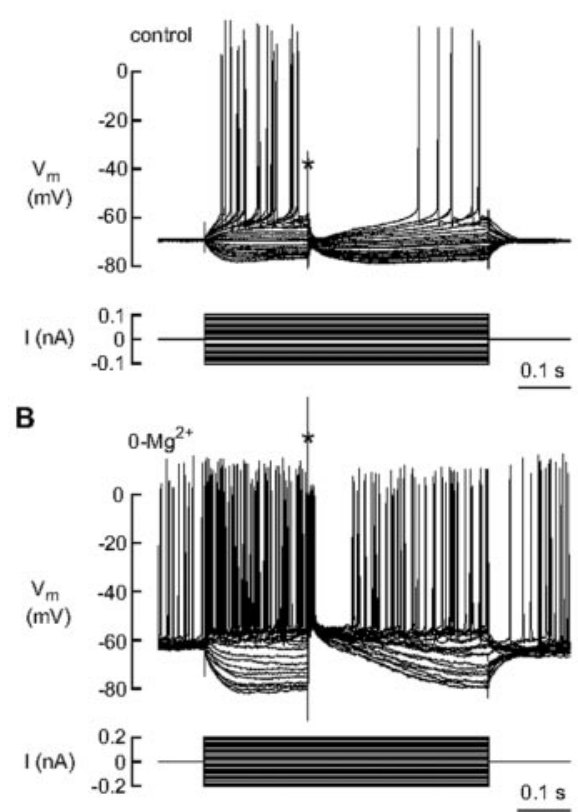

C

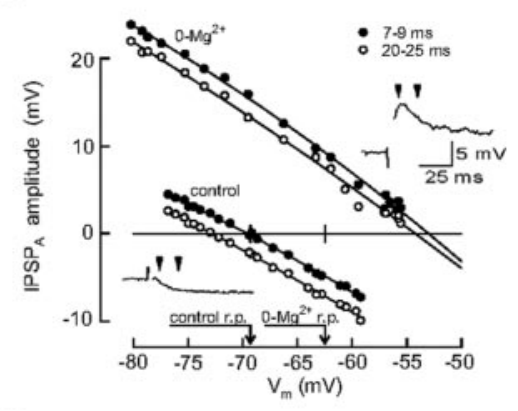

D

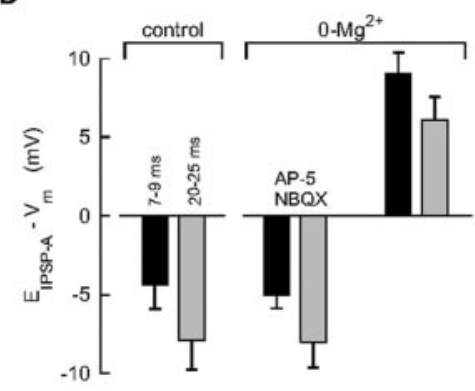

Figure 5. $\quad 0-\mathrm{Mg}^{2+}$-induced activity leads to a decrease in the efficacy of $\mathrm{Cl}^{-}$extrusion in $\mathrm{CA} 1$ pyramidal neurons. The IPSP reversal potential $\left(E_{\text {IPSP-A }}\right)$ was measured in the presence of NBQX plus AP- 5 using the $0.5 \mathrm{M} \mathrm{Cl}^{-}$-containing microelectrodes from control slices $(A)$ and after a $1-3 \mathrm{hr}$ period of $0-\mathrm{Mg}^{2+}$-induced activity $(B)$. Pharmacologically isolated IPSP $\mathrm{A}$ were evoked by electrical stimulation (asterisk) at various levels of membrane potential $\left(V_{m}\right.$; superimposed top traces) set by constant current pulses (bottom traces). The amplitudes of the IPSP $\mathrm{A}_{A}$ measured within two time windows (the time of stimulus taken as 0 ) from the recordings in $A$ and $B$ have been plotted against membrane potential in ( for detection of $E_{\text {IPSP-A }}$. The insets in ( show individual IPSP $_{A} s$ evoked from the resting membrane potential (r.p.) level, and the arrowheads indicate the two successive time windows used for $E_{\text {IPSP-A }}$ analysis (only the beginning of stimulus artifact is shown in the insets to indicate the timing of stimulation). $D$ shows a summary of the results under steady-state conditions in the presence of the electrode-induced $\mathrm{Cl}^{-}$load. Data are means \pm SEM of driving forces of IPSPs $\left(E_{\text {IPSP-A }}-V_{\mathrm{m}}\right.$ ) obtained from control cells $(n=8)$, from cells exposed to $0-\mathrm{Mg}^{2+}$ in the presence of NBQX plus AP-5 (to block interictal-like activity; $n=3)$, and from cells $(n=11)$ of slices that had undergone a $1-3 \mathrm{hr}$ period of $0-\mathrm{Mg}^{2+}$-induced activity before the intracellular recordings.

rated into the plasma membrane, display a very short lifetime. This fast turnover is further accelerated in an activity-dependent manner, which will make the plasmalemmal pool of KCC2 molecules even more susceptible to concomitant downregulation at the transcriptional level (Fig. $1 B$ ).

\section{Interictal-like activity leads to a fall in neuronal $\mathrm{Cl}^{-}$ extrusion capacity}

The activity-induced fall in KCC2 expression should be paralleled by a decrease in the neuronal $\mathrm{Cl}^{-}$extrusion capacity (Rivera et al., 1999). This prediction was studied in experiments on pharmacologically isolated $\mathrm{GABA}_{\mathrm{A}}$ receptor-mediated IPSPs $\left(\operatorname{IPSP}_{\mathrm{A}} \mathrm{s}\right)$. IPSP $\mathrm{A}_{\mathrm{A}} \mathrm{s}$ were evoked in the presence of NBQX plus AP-5, which also terminated the $0-\mathrm{Mg}^{2+}$-induced activity immediately before the intracellular measurements. We used microelectrodes containing $0.5 \mathrm{M} \mathrm{Cl}^{-}$because it is inappropriate to examine changes in the efficacy of ion extrusion in the absence of an ionic load (Bevensee and Boron, 1998; Jarolimek et al., 1999; Payne et al., 2003).

The IPSP $\mathrm{A}_{\mathrm{A}}$ had a fast initial component, with a delay of 3-7 msec and peak value at $8-13 \mathrm{msec}$ from the stimulus, followed by a more negative phase lasting tens of milliseconds (Fig. 5A-C) (Davies et al., 1990). These features of the "compound" IPSP evoked by simultaneous mass stimulation of somatic and dendritic inhibitory afferents (see Materials and Methods) are readily understood because (1) the experimentally induced $\mathrm{Cl}^{-}$load used was somatic, whereas extrusion of $\mathrm{Cl}^{-}$is mainly dendritic (Gulyas et al., 2001), and (2) the fastest inhibitory inputs acti-

vated in the present experiments are likely to be basket cells that target the somata of pyramidal neurons (Buhl et al., 1995). We therefore used two time windows when determining the reversal potential of IPSP $_{\mathrm{A}}$ $\left(E_{\text {IPSP-A }}\right)$ from responses recorded under steady-state conditions (Fig. 5C, insets). The mean driving force of $\operatorname{IPSP}_{\mathrm{A}} \mathrm{s}$ (defined here as $E_{\mathrm{IPSP}-\mathrm{A}}-V_{\mathrm{m}}$ ) at 7-9 and 20-25 msec after the stimulus pulse was $-4.4 \pm 1.5$ and $-7.9 \pm 1.9 \mathrm{mV}$ in control slices $(n=8)$ and $9.0 \pm 1.3$ and $6.1 \pm 1.4 \mathrm{mV}$ after $0-\mathrm{Mg}^{2+}$. induced activity $(n=11)$ (Fig. $5 D)$. The differences are statistically significant: $p=$ 0.000004 for control versus $0-\mathrm{Mg}^{2+}$ at $7-9$ msec, and $p=0.000015$ for control versus $0-\mathrm{Mg}^{2+}$ at $20-25 \mathrm{msec}$. The rather depolarizing reversal potentials were not affected by activation of voltage-gated $\mathrm{Na}^{+}$channels because adding QX-314 (50 mM) in the microelectrode filling solution caused a block of action potentials in the target cell, with no distinguishable effect on $E_{\mathrm{IPSP}-\mathrm{A}}(n=3)$; therefore, these data were pooled. Finally, the dependence of the depolarizing shift of $E_{\text {IPSP-A }}$ on the interictal-like activity was verified in experiments in which $E_{\text {IPSP-A }}$ values similar to those obtained under control conditions were seen after a 3-4 hr exposure to the $\mathrm{Mg}^{2+}$-free solution containing the glutamate antagonists $(n=3)$ (Fig. $5 D)$.

\section{TrkB activation by endogenous BDNF mediates activity induced downregulation of KCC2}

We have shown recently that KCC2 expression and, consequently, neuronal $\mathrm{Cl}^{-}$extrusion are downregulated after exposure to exogenous BDNF (Rivera et al., 2002). BDNF may induce hyperexcitability and has been postulated to be involved in epileptogenesis (Binder et al., 2001). With this in mind we hypothesized that activity-dependent downregulation of KCC2 as demonstrated in the present experiments would be mediated by endogenously released BDNF acting on TrkB receptors. To test this assumption, we superfused acute hippocampal slices with $0-\mathrm{Mg}^{2+}$ solution for $3 \mathrm{hr}$ in the presence or absence of the tyrosine kinase inhibitor K252a, which prevents TrkB activation by inhibiting autophosphorylation of the receptor. As shown in Figure 6, $A a$ and $A b$, KCC2 mRNA $(n=8)$ as well as protein levels $(110 \pm 5 \%)(n=8)$ remained at control levels in the presence of K252a. Control experiments showed that K252a had no detectable effect on the $0-\mathrm{Mg}^{2+}$-induced interictal-like activity $(n=3)$. We then performed similar experiments in which we scavenged endogenously released BDNF with TrkB receptor bodies (TrkB-Fc). We also found here (Fig. $6 B$ ) that the downregulation of KCC2 was attenuated, although the effect of TrkB-Fc was smaller ( $82 \pm 7 \% ; p<0.01 ; n=6)$. These results clearly show that TrkB activation by endogenous BDNF is needed for the activity-induced downregulation of KCC2.

\section{$0-\mathrm{Mg}^{2+}$-induced activity leads to CREB phosphorylation}

A known consequence of TrkB signaling is activation of the transcription factor CREB (Finkbeiner et al., 1997; Bibel and Barde, 
A

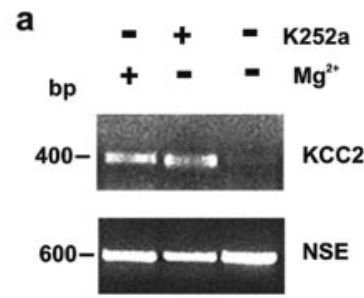

B

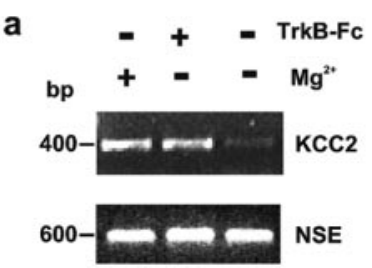

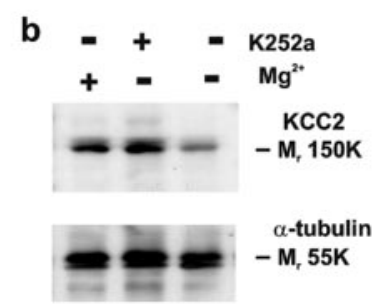

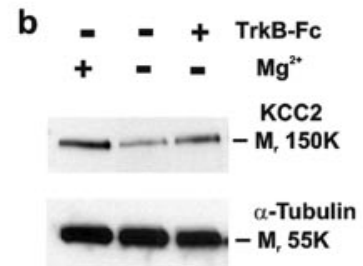

Figure 6. Endogenous BDNF mediates the activity-dependent downregulation of $\mathrm{KCC} 2$ in hippocampal slices. Aa, RT-PCR analysis showing block of $0-\mathrm{Mg}^{2+}$-induced $\mathrm{KCC} 2$ downregulation by the tyrosine kinase inhibitor K252a. NSE was used to confirm equal loading of total RNA. $A b$, K252a was also able to block downregulation of KCC2 protein levels as evidenced by Western blot analysis. $\alpha$-Tubulin was used to monitor an equal amount of total protein per lane. $B$, Scavenging endogenous BDNF with TrkB-Fc also inhibited the $0-\mathrm{Mg}^{2+}$-induced downregulation of KCC2 mRNA $(B a)$ and protein $(B b)$ levels.

2000; Minichiello et al., 2002). We examined regional CREB activation in slices that had been superfused with $0-\mathrm{Mg}^{2+}$ solution using an $\mathrm{Ab}$ that specifically recognizes $\mathrm{CREB}$ phosphorylated at Ser-133 (pCREB). We observed a distinct increase in CREB activation in the CA1 region and dentate gyrus in slices superfused for $1 \mathrm{hr}$ with $0-\mathrm{Mg}^{2+}$ solution (Fig. $\left.7 \mathrm{Aa}, \mathrm{Ab}\right)(n=4)$. After $3 \mathrm{hr}$ in $0-\mathrm{Mg}^{2+}$ solution, an increase in Ser-133 phosphorylation levels was also found in CA3 (Fig. 7Ac,Ad) $(n=4)$. Interestingly, parallel Western blot analyses (Fig $7 B$ ) showed that $0-\mathrm{Mg}^{2+}$-induced CREB activation (176 $\pm 15 \% ; p<0.001 ; n=4)$ was fully blocked $(91 \pm 8 \% ; n=4)$ if not reversed by scavenging endogenous BDNF with TrkB-Fc, indicating that CREB activation in this paradigm is mediated at least partly by TrkB activation and may have a role in the downregulation of KCC2 expression in the hippocampus.

\section{Activation of TrkB PLC $\gamma$ and Shc docking sites are required} for downregulation of KCC2

BDNF-TrkB signaling is mediated by well known intracellular signaling cascades, including the PLC $\gamma$-CaM kinase pathway as well as the phosphoinositide 3 kinase and Ras/MAPK (mitogen-activated protein kinase) pathways. These cascades are selectively activated by the recruitment of adaptor proteins such as PLC $\gamma$ that bind to TrkB phosphotyrosine 816 , and by Shc/ FRS-2, which binds to TrkB phosphotyrosine 515 (Finkbeiner et al., 1997; Bibel and Barde, 2000; Minichiello et al., 2002). To investigate the signaling cascades triggered by BDNF via TrkB involved in the mechanism for downregulation of KCC2, we made use of a recently developed transgenic mice targeted mutation in the PLC $\gamma$ docking site of TrkB (trkB ${ }^{P L C / P L C}$ mice), where $\operatorname{Tyr}^{816}$ was replaced by Phe and a strain with a similar point mutation
(Tyr515Phe) in the Shc binding site (trkB ${ }^{S H C / S H C}$ mice) (Minichiello et al., 1998, 2002). Acute hippocampal slices were treated with 100 $\mathrm{ng} / \mathrm{ml} \mathrm{BDNF}$ for $3-4 \mathrm{hr}$. In control trkB ${ }^{w / w}$ slices (5 mice; 10 slices per mouse and treatment) (Minichiello et al., 2002), BDNF application induced, as could be expected, a downregulation of KCC2 protein levels (Fig. 8 B, left). In the trkB ${ }^{S H C / S H C}$ mutant slices ( 5 mice; 10 slices per mouse and treatment), KCC2 protein levels were not significantly affected by BDNF, indicating that activation of the Shc-site cascade is necessary for KCC2 downregulation (Fig. $8 B$, middle). A striking observation was that in the $\operatorname{trkB}^{P L C / P L C}$ mutant slices (5 mice; 10 slices per mouse and treatment), KCC2 protein levels were elevated by the exposure to BDNF, indicating that when acting in the absence of the PLC $\gamma$ cascade, the Shc pathway upregulates KCC2 (Fig. $8 B$, right).

Additional evidence for the conclusion (see above) that endogenous BDNF mediates the activity-dependent downregulation of KCC2 was obtained from experiments in which slices from TrkB mutant mice were exposed to the $0-\mathrm{Mg}^{2+}$ solution for $3 \mathrm{hr}$ (4 mice; 10 slices per mouse and treatment) (Fig. 8C). A block of this downregulation was evident in Western blots from slices from the trkB ${ }^{\mathrm{SHC} / \mathrm{SHC}}$ mice, whereas an increase in KCC2 protein took place in the trkB ${ }^{\mathrm{PLC} / \mathrm{PLC}}$ tissue. The quantitative data from the above BDNF and $0-\mathrm{Mg}^{2+}$ experiments are shown in Figure $8 D$.

\section{Discussion}

The main novel findings of the present work include, first, a dramatic downregulation of KCC2 that is strictly dependent on neuronal hyperactivity. At the functional level, this is shown to compromise neuronal $\mathrm{Cl}^{-}$extrusion required for GABAergic postsynaptic hyperpolarization. Second, the surprisingly high turnover rate of membrane-bound KCC2 points to changes in KCC2 expression as a novel mechanism in the control of neuronal plasticity via changes in the efficacy of inhibition. Interestingly, a recent report has shown a $\mathrm{Ca}^{2+}$-dependent decrease in $\mathrm{K}-\mathrm{Cl}$ cotransport activity associated with coincident presynaptic and postsynaptic spiking (Woodin et al., 2003). Whether this effect shares mechanisms of the kind studied here is an interesting question to be examined in future studies. In addition, our results provide an explanation for the fast qualitative change in GABAergic transmission from hyperpolarizing to depolarizing that has been
A
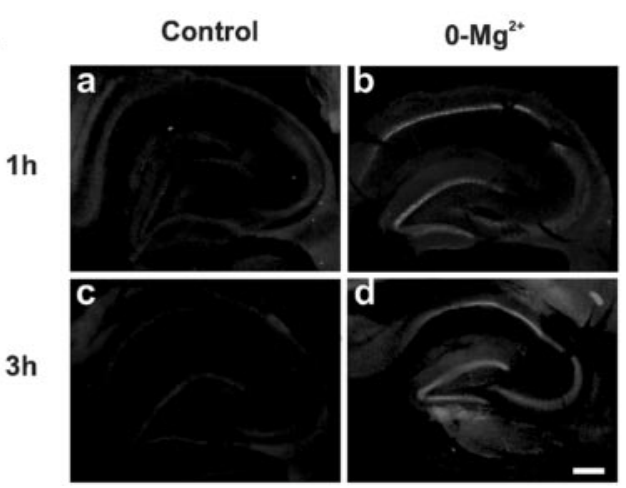

\section{B}

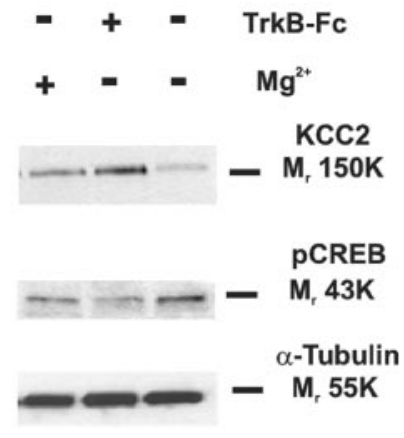

Figure 7. TrkB is a major mediator of $0-\mathrm{Mg}^{2+}$-induced CREB phosphorylation in hippocampal slices. $A$, Immunofluorescent staining showing $0-\mathrm{Mg}^{2+}$-induced increase in CREB phosphorylation. After $1 \mathrm{hr}$ in $0-\mathrm{Mg}^{2+}$ solution, slices showed robust increase in anti- pCREB nuclear immunoreactivity in the CA1 region and dentate gyrus as compared with parallel control slices. After $3 \mathrm{hr}$ in $0-\mathrm{Mg}^{2+}$ solution, the level of activated CREB increased further and reached the CA3 region. Scale bar, $900 \mu \mathrm{m}$. B, Comparison of KCC2 and pCREB expression by Western blot analysis of $0-\mathrm{Mg}^{2+}$-superfused (3 hr) hippocampal slices in the presence or absence of TrkB-Fc showing that scavenging of endogenous BDNF blocks CREB phosphorylation. $\alpha$-Tubulin was used to monitor the amount of total protein. 


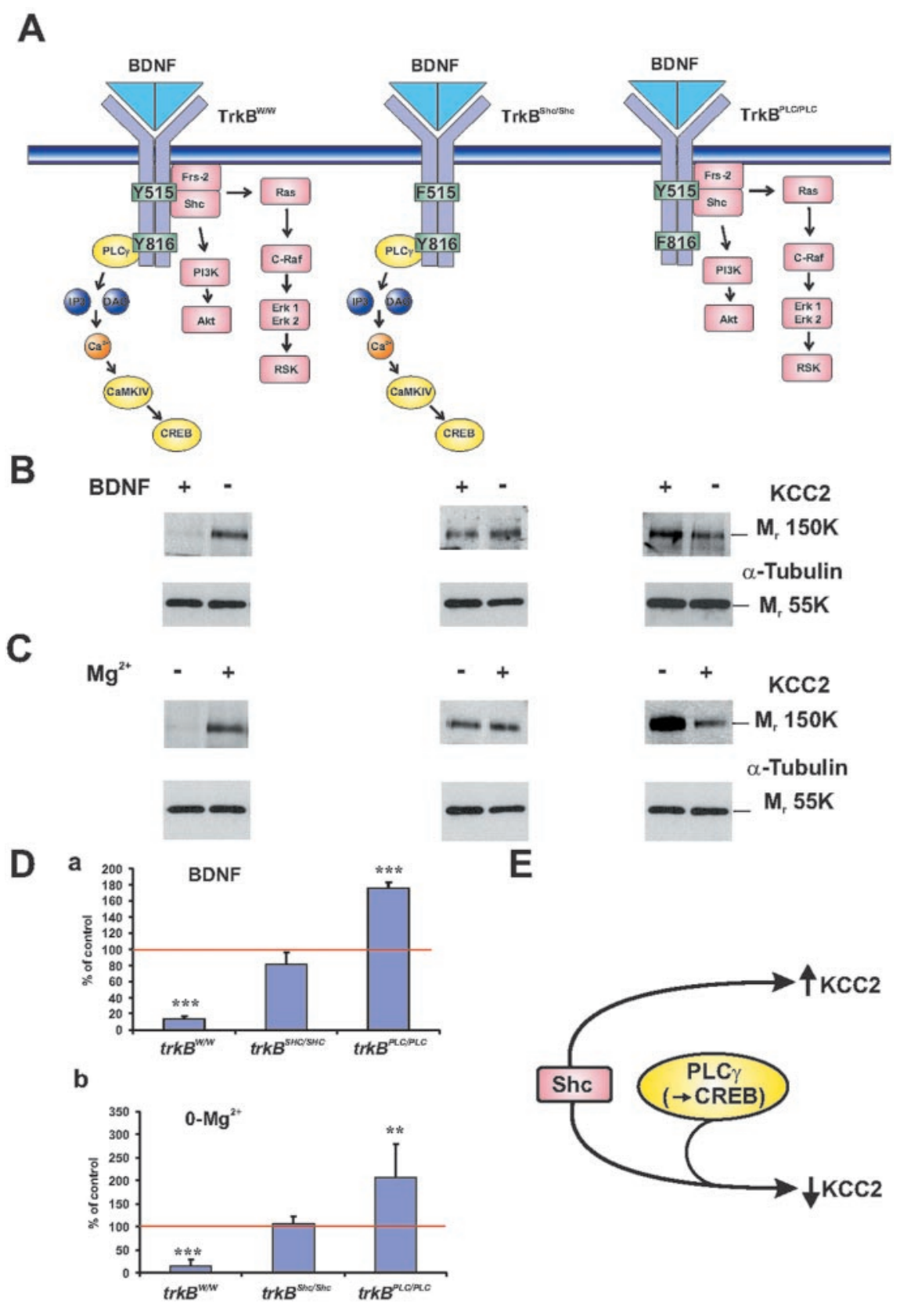

Figure 8. Both PLC $\gamma$ and Shc docking sites of TrkB are required for BDNF-TrkB-mediated KCC2 downregulation, whereas the Shc site acting in isolation mediates an upregulation of KCC2. A, Schematic representation of the mutant TrkB receptors with a point mutation at either the tyrosine 515 or Shcsite in the juxtamembrane region (Minichiello et al., 1998) or at the tyrosine 816 or PLC $\gamma$ site in the C-terminal region. The trkB ${ }^{W W}$ is a control-strategy receptor for the trkB ${ }^{P L C / P L C}$ mutant receptor (Minichiello et al., 2002). In the trkB ${ }^{P L C / P L C}$ and $\operatorname{trkB}^{\text {SHC/SHC }}$ mutant receptors, tyrosine (Y816) and tyrosine (Y515) were replaced by phenylalanine (F816) and phenylalanine (F515), respectively. $B$, Western blot analysis of BDNF-exposed (3-4 hr) acute slices from the point-mutant mice. In the control trkB ${ }^{W W}$ mice, BDNF induced downregulation of $\mathrm{KCC} 2$ as expected. On the contrary, $\mathrm{KCC} 2$ was not downregulated in the trkB ${ }^{\mathrm{SHC} / S H C}$ mutants, indicating that the Shc/FRS-2-coupled pathway is important for KCC2 downregulation. Strikingly, KCC2 was upregulated by BDNF in the trkB ${ }^{P L C / P L C}$ mutant mice. C, Western blot analysis of slices from the knock-in mice exposed for $3 \mathrm{hr}$ to the $0-\mathrm{Mg}^{2+}$ solution shows effects similar to those mediated by BDNF: the $0-\mathrm{Mg}^{2+}$-induced $\mathrm{KCC} 2$ downregulation was blocked in the $\mathrm{trkB}^{\mathrm{SHC} / \mathrm{SHC}}$ mutant slices, and a clear upregulation was seen in trkB ${ }^{P L C P L C} . \alpha$-Tubulin was used to monitor the amount of total protein. D, Plot of band intensities from experiments in $B$ and $C$ (means \pm SEM; $t$ test; ${ }^{* * *} p<0.001 ;{ }^{* *} p<0.01$ ). E, Scheme interpreting the data obtained with the trkB mutant mice. Activation of both Shc and PLC $\gamma$ cascades is required for trkB-mediated downregulation of KCC2, whereas activation of the Shc pathway in the absence of PLC $\gamma$ activation leads to an upregulation of KCC2.

reported to take place during neuronal trauma (Kapur et al., 1995; van den Pol et al., 1996; Kaila et al., 1997; Nabekura et al., 2002; Toyoda et al., 2001; Payne et al., 2003). Third, the near-complete block by TrkB-Fc of activity-induced KCC2 downregulation in a widely used in vitro preparation implies an important role for endogenous BDNF in the postsynaptic modulation of the ionic mechanisms underlying GABAergic events. Finally, the analysis of transgenic mice $\left(\operatorname{trk} B^{S H C / S H C}\right.$ and $\left.\operatorname{trk} B^{P L C / P L C}\right)$ carrying point mutations that selectively disable intracellular signaling cascades triggered by PLC $\gamma$ or Shc/FRS-2 docking to TrkB indicated the presence of distinct TrkB-mediated cascades resulting in KCC2 downregulation and upregulation (PLC $\gamma$ plus Shc; Shc in isolation). The requirement of the joint operation of these two pathways for KCC2 downregulation is in itself intriguing. On the other hand, the upregulation mediated by the Shc pathway in isolation serves as an obvious starting point for future work on the molecular mechanisms underlying the ontogenetic upregulation of KCC2 and the associated "developmental switch" in GABAergic transmission (Rivera et al., 1999; Aguado et al., 2003; Ludwig et al., 2003).

\section{Activity-dependent downregulation of KCC2 expression}

In a recent study we reported that KCC2 mRNA and protein levels were significantly lower in the hippocampus in vivo after kindling-induced seizures (Rivera et al., 2002), suggesting that the expression of KCC2 would be downregulated by pathophysiological activity. Direct evidence supporting this hypothesis was obtained in experiments on hippocampal slices exposed to $0-\mathrm{Mg}^{2+}$, in which the interictal-like spontaneous activity (Anderson et al., 1986; Mody et al., 1987) led to downregulation of KCC2 that was blocked by pharmacological inhibition of neuronal activity.

Immunofluorescent KCC2 staining in slices exposed to the $0-\mathrm{Mg}^{2+}$ solution showed that the downregulation of KCC2 displayed an intriguing spatiotemporal profile. A salient feature here was the marked fall in KCC2 levels in the CA1 dendritic region that was much faster than in CA3. This is an interesting finding also in the light of recent evidence that suppression of dendritic inhibition is strongly proconvulsant (Cossart et al., 2001).

The experiments on cell-surface biotinylated KCC2 showed that the plasmalemmal pool of KCC2 has a strikingly fast turnover rate, which provides a time window for modulatory actions at the level of synaptic transmission similar to that of glutamate receptor subunits (Ehlers, 2000; Lin et al., 2000; Thomas-Crusells et al., 2003). The rate of decay of the surface-biotinylated KCC2 protein was increased further in an activity-dependent manner. Obviously, this activity-dependent increase in the turnover of the plasmalemmal KCC2 transporters enhances their suscep- 
tibility to downregulation that takes place at the transcriptional level.

\section{Interictal-like activity leads to a fall in the efficacy of neuronal $\mathrm{Cl}^{-}$extrusion}

The prediction that the fall in plasmalemmal KCC2 is paralleled by an activity-dependent decrease in the efficacy of $\mathrm{Cl}^{-}$extrusion by pyramidal neurons was verified in experiments in which $E_{\text {IPSP-A }}$ was measured in neurons subjected to a tonic chloride load with a $0.5 \mathrm{M} \mathrm{Cl}^{-}$-containing sharp microelectrode. Control cells turned out to be able to maintain a mean level of $E_{\text {IPSP-A }}$ more negative than resting $V_{\mathrm{m}}$, despite the load, whereas neurons that had undergone $0-\mathrm{Mg}^{2+}$-induced hypersynchronous activity had a depolarizing reversal potential, showing that the capacity of the afflicted cells to deal with $\mathrm{Cl}^{-}$loads had been strongly compromised. Notably, a similar impairment of neuronal $\mathrm{Cl}^{-}$extrusion was achieved with application of exogenous BDNF on acute hippocampal slices (Rivera et al., 2002). These results also shed light on previous findings from in vivo and in vitro models of epilepsy as well as from human epileptic tissue that have demonstrated a positive shift in the driving force of $\mathrm{GABA}_{\mathrm{A}}$-mediated inhibition, which is sometimes large enough to change the postsynaptic response from hyperpolarizing to depolarizing (Tasker et al., 1992; Avoli et al., 1995; Kapur and Coulter, 1995; Kohling et al., 2000; Cohen et al., 2002).

\section{Molecular mechanism of TrkB-mediated KCC2 downregulation}

BDNF-TrkB-mediated signaling appears to be a major link between neuronal activity and changes in protein expression required for long-term plasticity such as long-term potentiation (LTP) and epileptogenesis (Kokaia et al., 1995; Thoenen, 1995; Binder et al., 1999; Croll et al., 1999; Lu and Chow, 1999; Lu and Gottschalk, 2000).

The results presented here show clearly that $0-\mathrm{Mg}^{2+}$-induced spontaneous activity is able to induce BDNF release and activation of TrkB receptors, which subsequently leads to downregulation of KCC2. This was evident from the experiments in which $0-\mathrm{Mg}^{2+}$ induced KCC2 downregulation was inhibited by blocking TrkB with K252a and by scavenging endogenous BDNF with TrkB-Fc. The fact that the downregulation was inhibited slightly more efficiently by K252a may suggest that other endogenous trophic factors in addition to BDNF make a small contribution to this process.

Scavenging endogenous BDNF also suppressed the increase in CREB activation that was observed in slices exposed to the $0-\mathrm{Mg}^{2+}$ solution. The temporal and spatial distribution observed by immunofluorescent staining for pCREB (Fig. 7) is consistent with the idea that CREB activation is required for downregulation of KCC2 as seen in KCC2 immunostainings (Fig. 2). The robust increase in CREB phosphorylation observed in the CA1 region after $1 \mathrm{hr}$ showed a good match not only with the downregulation of KCC2 in the same region but also with the pattern of previously reported BDNF-induced CREB activation in the hippocampus (Finkbeiner et al., 1997).

Two major intracellular cascades have been shown to be involved in plasticity-related effects of BDNF in the hippocampus. Using two strains of mice with a single amino acid-targeted mutation of the TrkB gene that abolish binding of either PLC $\gamma$ or Shc/FRS-2 to the TrkB receptor, respectively, Minichiello et al. (2002) showed that PLC $\gamma$-CREB signaling is necessary for LTP, whereas TrkB-coupled activation of the Shc pathway is not required (Ernfors and Bramham, 2003). We used the same transgenic mice ( $\operatorname{trkB}^{P L C / P L C}$ and $\operatorname{trk} B^{S H C / S H C}$ ) to identify the mecha- nisms required for BDNF-TrkB-mediated downregulation of KCC2. Perhaps somewhat unexpectedly, we found that both the PLC $\gamma$ and Shc/FRS-2-activated signaling cascades are required for KCC2 downregulation caused by the $0-\mathrm{Mg}^{2+}$ solution and by exogenous BDNF $(n=5)$. Furthermore, with deletion of the PLC $\gamma$-coupled pathway, both $0-\mathrm{Mg}^{2+}$ and BDNF triggered an intriguing upregulation of $\mathrm{KCC} 2(n=5)$.

Taken together, the data obtained using slices from the trk$\mathrm{B}^{\text {PLC/PLC }}$ and trkB ${ }^{S H C / S H C}$ mice suggest that the Shc pathway is crucial for both the downregulation and upregulation of KCC2. Downregulation of KCC2 appears to take place if the Shc pathway is activated in conjunction with the PLC $\gamma$ cascade, whereas an upregulation is triggered by the Shc pathway acting in the absence of the PLC $\gamma$ cascades. A particularly interesting question for future work is whether such data will shed light on the mechanisms that control the developmental upregulation of KCC2 (Rivera et al., 1999), which is known to be crucial for the maturation of functional postsynaptic inhibition in the CNS.

A recent report by Aguado et al. (2003) showed that in the late prenatal hippocampus, BDNF may have an upregulatory effect on KCC2 mRNA expression. The apparently opposite actions of BDNF on KCC2 expression in immature versus mature neurons is likely to reflect the activation of the distinct TrkB-linked signaling pathways (Fig. 8). It is interesting to note that a similar development-related qualitative difference in BDNF action has been reported for $\mathrm{GABA}_{\mathrm{A}}$ receptor trafficking (Mizoguchi et al., 2003). Finally, the present results suggest that a downregulation of KCC2 may be a general early response involved in various kinds of neuronal trauma (Kapur and Coulter, 1995; van den Pol et al., 1996; Kaila et al., 1997; Toyoda et al., 2001; Nabekura et al., 2002; Payne et al., 2003).

\section{References}

Aguado F, Carmona MA, Pozas E, Aguilo A, Martinez-Guijarro FJ, Alcantara S, Borrell V, Yuste R, Ibanez CF, Soriano E (2003) BDNF regulates spontaneous correlated activity at early developmental stages by increasing synaptogenesis and expression of the $\mathrm{K}^{+} / \mathrm{Cl}^{-}$co-transporter KCC2. Development 130:1267-1280.

Anderson WW, Lewis DV, Swartzwelder HS, Wilson WA (1986) Magnesiumfree medium activates seizure-like events in the rat hippocampal slice. Brain Res 398:215-219.

Avoli M (1996) GABA-mediated synchronous potentials and seizure generation. Epilepsia 37:1035-1042.

Avoli M, Louvel J, Drapeau C, Pumain R, Kurcewicz I (1995) GABA A mediated inhibition and in vitro epileptogenesis in the human neocortex. J Neurophysiol 73:468-484.

Beau FE, Alger BE (1998) Transient suppression of GABAA-receptormediated IPSPs after epileptiform burst discharges in CA1 pyramidal cells. J Neurophysiol 79:659-669.

Bevensee MO, Boron WF (1998) Thermodynamics and physiology of cellular $\mathrm{pH}$ regulation. In: $\mathrm{pH}$ and brain function (Kaila K, Ransom BR, eds), pp 173-194. New York: Wiley.

Bibel M, Barde YA (2000) Neurotrophins: key regulators of cell fate and cell shape in the vertebrate nervous system. Genes Dev 14:2919-2937.

Binder DK, Routbort MJ, Ryan TE, Yancopoulos GD, McNamara JO (1999) Selective inhibition of kindling development by intraventricular administration of TrkB receptor body. J Neurosci 19:1424-1436.

Binder DK, Croll SD, Gall CM, Scharfman HE (2001) BDNF and epilepsy: too much of a good thing? Trends Neurosci 24:47-53.

Buhl EH, Cobb SR, Halasy K, Somogyi P (1995) Properties of unitary IPSPs evoked by anatomically identified basket cells in the rat hippocampus. Eur J Neurosci 7:1989-2004.

Chomczynski P, Sacchi N (1987) Single-step method of RNA isolation by acid guanidinium thiocyanate-phenol-chloroform extraction. Anal Biochem 162:156-159.

Cohen I, Navarro V, Clemenceau S, Baulac M, Miles R (2002) On the origin of interictal activity in human temporal lobe epilepsy in vitro. Science 298:1418-1421. 
Cossart R, Dinocourt C, Hirsch JC, Merchan-Perez A, De Felipe J, Ben Ari Y, Esclapez M, Bernard C (2001) Dendritic but not somatic GABAergic inhibition is decreased in experimental epilepsy. Nat Neurosci 4:52-62.

Croll SD, Suri C, Compton DL, Simmons MV, Yancopoulos GD, Lindsay RM, Wiegand SJ, Rudge JS, Scharfman HE (1999) Brain-derived neurotrophic factor transgenic mice exhibit passive avoidance deficits, increased seizure severity and in vitro hyperexcitability in the hippocampus and entorhinal cortex. Neuroscience 93:1491-1506.

Davies CH, Davies SN, Collingridge GL (1990) Paired-pulse depression of monosynaptic GABA-mediated inhibitory postsynaptic responses in rat hippocampus. J Physiol (Lond) 424:513-531.

DeFazio RA, Keros S, Quick MW, Hablitz JJ (2000) Potassium-coupled chloride cotransport controls intracellular chloride in rat neocortical pyramidal neurons. J Neurosci 20:8069-8076.

Ehlers MD (2000) Reinsertion or degradation of AMPA receptors determined by activity-dependent endocytic sorting. Neuron 28:511-525.

Ernfors P, Bramham CR (2003) The coupling of a trkB tyrosine residue to LTP. Trends Neurosci 26:171-173.

Finkbeiner S, Tavazoie SF, Maloratsky A, Jacobs KM, Harris KM, Greenberg ME (1997) CREB: a major mediator of neuronal neurotrophin responses. Neuron 19:1031-1047.

Ganguly K, Schinder AF, Wong ST, Poo M (2001) GABA itself promotes the developmental switch of neuronal GABAergic responses from excitation to inhibition. Cell 105:521-532.

Gulyas AI, Sik A, Payne JA, Kaila K, Freund TF (2001) The KCl cotransporter, KCC2, is highly expressed in the vicinity of excitatory synapses in the rat hippocampus. Eur J Neurosci 13:2205-2217.

Hiltunen JO, Arumae U, Moshnyakov M, Saarma M (1996) Expression of mRNAs for neurotrophins and their receptors in developing rat heart. Circ Res 79:930-939.

Hubner CA, Stein V, Hermans-Borgmeyer I, Meyer T, Ballanyi K, Jentsch TJ (2001) Disruption of KCC2 reveals an essential role of $\mathrm{K}-\mathrm{Cl}$ cotransport already in early synaptic inhibition. Neuron 30:515-524.

Jackson MF, Esplin B, Capek R (1999) Inhibitory nature of tiagabineaugmented $\mathrm{GABA}_{\mathrm{A}}$ receptor-mediated depolarizing responses in hippocampal pyramidal cells. J Neurophysiol 81:1192-1198.

Jarolimek W, Lewen A, Misgeld U (1999) A furosemide-sensitive $\mathrm{K}^{+}-\mathrm{Cl}^{-}$ cotransporter counteracts intracellular $\mathrm{Cl}^{-}$accumulation and depletion in cultured rat midbrain neurons. J Neurosci 19:4695-4704.

Kaila K (1994) Ionic basis of $\mathrm{GABA}_{\mathrm{A}}$ receptor channel function in the nervous system. Prog Neurobiol 42:489-537.

Kaila K, Lamsa K, Smirnov S, Taira T, Voipio J (1997) Long-lasting GABAmediated depolarization evoked by high-frequency stimulation in pyramidal neurons of rat hippocampal slice is attributable to a networkdriven, bicarbonate-dependent $\mathrm{K}^{+}$transient. J Neurosci 17:7662-7672.

Kakazu Y, Uchida S, Nakagawa T, Akaike N, Nabekura J (2000) Reversibility and cation selectivity of the $\mathrm{K}(+)-\mathrm{Cl}(-)$ cotransport in rat central neurons. J Neurophysiol 84:281-288.

Kapur J, Coulter DA (1995) Experimental status epilepticus alters gammaaminobutyric acid type A receptor function in CA1 pyramidal neurons. Ann Neurol 38:893-900.

Kohling R, Vreugdenhil M, Bracci E, Jefferys JG (2000) Ictal epileptiform activity is facilitated by hippocampal $\mathrm{GABA}_{\mathrm{A}}$ receptor-mediated oscillations. J Neurosci 20:6820-6829.

Kokaia M, Ernfors P, Kokaia Z, Elmer E, Jaenisch R, Lindvall O (1995) Suppressed epileptogenesis in BDNF mutant mice. Exp Neurol 133:215-224.

Köhling R, Lucke A, Straub H, Speckmann EJ, Tuxhorn I, Wolf P, Pannek H, Oppel F (1998) Spontaneous sharp waves in human neocortical slices excised from epileptic patients. Brain 121:1073-1087.

Lamsa K, Kaila K (1997) Ionic mechanisms of spontaneous GABAergic events in rat hippocampal slices exposed to 4-aminopyridine. J Neurophysiol 78:2582-2591.

Lin JW, Ju W, Foster K, Lee SH, Ahmadian G, Wyszynski M, Wang YT, Sheng M (2000) Distinct molecular mechanisms and divergent endocytotic pathways of AMPA receptor internalization. Nat Neurosci 3:1282-1290.

Lu B, Chow A (1999) Neurotrophins and hippocampal synaptic transmission and plasticity. J Neurosci Res 58:76-87.

Lu B, Gottschalk W (2000) Modulation of hippocampal synaptic transmission and plasticity by neurotrophins. Prog Brain Res 128:231-241.

Lu J, Karadsheh M, Delpire E (1999) Developmental regulation of the neuronal-specific isoform of $\mathrm{K}-\mathrm{Cl}$ cotransporter $\mathrm{KCC} 2$ in postnatal rat brains. J Neurobiol 39:558-568.

Ludwig A, Li H, Saarma M, Kaila K, Rivera C (2003) Developmental upregulation of KCC2 in the absence of GABAergic and glutamatergic transmission. Eur J Neurosci 18:3199-3206.

Mellman I (1996) Endocytosis and molecular sorting. Annu Rev Cell Dev Biol 12:575-625.

Minichiello L, Casagranda F, Tatche RS, Stucky CL, Postigo A, Lewin GR, Davies AM, Klein R (1998) Point mutation in trkB causes loss of NT4dependent neurons without major effects on diverse BDNF responses. Neuron 21:335-345.

Minichiello L, Calella AM, Medina DL, Bonhoeffer T, Klein R, Korte M (2002) Mechanism of TrkB-mediated hippocampal long-term potentiation. Neuron 36:121-137.

Mizoguchi Y, Ishibashi H, Nabekura J (2003) The action of BDNF on $\mathrm{GABA}_{\mathrm{A}}$ currents changes from potentiating to suppressing during maturation of rat hippocampal CA1 pyramidal neurons. J Physiol (Lond) 548:703-709.

Mody I, Lambert JD, Heinemann U (1987) Low extracellular magnesium induces epileptiform activity and spreading depression in rat hippocampal slices. J Neurophysiol 57:869-888.

Nabekura J, Ueno T, Okabe A, Furuta A, Iwaki T, Shimizu-Okabe C, Fukuda A, Akaike N (2002) Reduction of KCC2 expression and $\mathrm{GABA}_{\mathrm{A}}$ receptor-mediated excitation after in vivo axonal injury. $\mathrm{J}$ Neurosci 22:4412-4417.

Nieto MA, Patel K, Wilkinson DG (1996) In situ hybridization analysis of chick embryos in whole mount and tissue sections. Methods Cell Biol 51:219-235.

Payne JA, Stevenson TJ, Donaldson LF (1996) Molecular characterization of a putative $\mathrm{K}-\mathrm{Cl}$ cotransporter in rat brain. A neuronal-specific isoform. J Biol Chem 271:16245-16252.

Payne JA, Rivera C, Voipio J, Kaila K (2003) Cation-chloride co-transporters in neuronal communication, development and trauma. Trends Neurosci 26:199-206.

Poirier JL, Capek R, De Koninck Y (2000) Differential progression of dark neuron and fluoro-jade labeling in the rat hippocampus following pilocarpine-induced status epilepticus. Neuroscience 97:59-68.

Rivera C, Voipio J, Payne JA, Ruusuvuori E, Lahtinen H, Lamsa K, Pirvola U, Saarma M, Kaila K (1999) The $\mathrm{K}^{+} / \mathrm{Cl}^{-}$co-transporter KCC2 renders GABA hyperpolarizing during neuronal maturation. Nature 397:251-255.

Rivera C, Li H, Thomas-Crusells J, Lahtinen H, Viitanen T, Nanobašhvili A, Kokaia K, Airaksinen MS, Voipio J, Kaila K, Saarma M (2002) BDNFinduced TrkB activation downregulates the $\mathrm{K}^{+}-\mathrm{Cl}^{-}$cotransporter KCC2 and impairs neuronal $\mathrm{Cl}^{-}$extrusion. J Cell Biol 159:747-752.

Schmidt-Kastner R, Freund TF (1991) Selective vulnerability of the hippocampus in brain ischemia. Neuroscience 40:599-636.

Tasker JG, Peacock WJ, Dudek FE (1992) Local synaptic circuits and epileptiform activity in slices of neocortex from children with intractable epilepsy. J Neurophysiol 67:496-507.

Thoenen H (1995) Neurotrophins and neuronal plasticity. Science 270:593-598.

Thomas-Crusells J, Vieira A, Saarma M, Rivera C (2003) A novel method for monitoring surface membrane trafficking on hippocampal acute slice preparation. J Neurosci Methods 125:159-166.

Thompson SM, Gähwiler BH (1989) Activity-dependent disinhibition. II. Effects of extracellular potassium, furosemide, and membrane potential on $\mathrm{ECl}^{-}$in hippocampal CA3 neurons. J Neurophysiol 61:512-523.

Toyoda H, Ohno K, Yamada J, Ikeda M, Okabe A, Sato K, Hashimoto K, Fukuda A (2001) Induction of NMDA and GABAA receptor-mediated $\mathrm{Ca}^{2+}$ oscillations with KCC2 mRNA downregulation in injured facial motoneurons. J Neurophysiol 89:1353-1362.

van den Pol AN, Obrietan K, Chen G (1996) Excitatory actions of GABA after neuronal trauma. J Neurosci 16:4283-4292.

Voipio J, Kaila K (2000) GABAergic excitation and $\mathrm{K}^{+}$-mediated volume transmission in the hippocampus. Prog Brain Res 125:329-338.

Williams JR, Sharp JW, Kumari VG, Wilson M, Payne JA (1999) The neuron-specific K-Cl cotransporter, KCC2. Antibody development and initial characterization of the protein. J Biol Chem 274:12656-12664.

Woodin MA, Ganguly K, Poo MM (2003) Coincident pre- and postsynaptic activity modifies GABAergic synapses by postsynaptic changes in $\mathrm{Cl}^{-}$ transport activity. Neuron 39:807-820. 